\title{
A Study on Science Education of Chinese English Textbooks in Senior High School from the Perspective of Multimodality
}

\author{
Bin Lu ${ }^{1,2, *}$, Shengyan $\mathrm{Shi}^{2}$ \\ ${ }^{1}$ School of Management, Shinawatra University, Bangkok, Thailand \\ ${ }^{2}$ School of Foreign Languages, Luoyang Normal University, Luoyang, China \\ Email address: \\ 2423905702@qq.com (Bin Lu), 2118903450@qq.com (Shengyan Shi) \\ *Corresponding author
}

\section{To cite this article:}

Bin Lu, Shengyan Shi. A Study on Science Education of Chinese English Textbooks in Senior High School from the Perspective of Multimodality. Education Journal. Vol. 9, No. 6, 2020, pp. 179-194. doi: 10.11648/j.edu.20200906.15

Received: December 7, 2020; Accepted: December 25, 2020; Published: December 31, 2020

\begin{abstract}
With the advent of the post epidemic era, discourse analysis based on systemic functional linguistics has undergone corresponding changes. As one of the key categories of science discourse, the discourse of science education has become one of the research hot spots. The reasonable arrangement, presentation and proportion of Chinese science education in English textbooks of senior high school are of positive significance to improve students' scientific literacy and broaden their horizons. This study aims to analyze the discourse of science education, including the contents, integration forms, meaning construction, relation between image and text by using qualitative methods and investigate the attitude of teachers towards science education in Chinese English textbooks of senior high school by using quantitative methods from the perspective of multimodality based on textbook evaluation theory, visual grammar, and relation theory of image and text. A total of 228 teachers from five different Chinese cities as Anyang, Luoyang, Luohe, Xuchang were investigated. The conclusion are: (1) it should pay attention to increase cognition education of science and technology frontier, design the content of science education more scientifically; (2) it should pay attention to use multimodality to strengthen science education rather than single modal; (3) it should adopt the presentation forms of multimodality which teachers and students prefer and easy to accept in order to improve the teaching effect and guidance of science education in senior high school.
\end{abstract}

Keywords: Chinese Science Education, English Textbooks, Textbook Evaluation

\section{Introduction}

In the main Chinese research field of science education, Tiequan Cai, Lihua Chen [1] summarized it into 18 aspects, namely, scientific literacy, STS, constructivism of integrated curriculum, educational resources, and etc. English textbooks, as one of important educational resources, its corpus of science education is abundant, but there are few researches on science education in English textbooks of senior high school. Although it is involved, it is only part of the content, and there is no comprehensive research on it. It can be divided into two main research directions: firstly, only focus on English textbooks, but don't focus on the comparison of the allocation of science education; secondly, only focus on part of articles of science education. Some research extract several discourses of science through quantitative and qualitative analysis by using the three meta functions of Halliday's systemic functional grammar. The discourse of science has become one of the new hot spots in systemic functional linguistics in the post epidemic era [2-4]. However, there are few researches on discourses of science education in English textbooks of senior high school. Discourse of science refers to the scientific knowledge, scientific spirit, scientific behavior presented by various discourses of science. Educational discourse plays an important role in the process of ideograph, especially in the process of education and cultural communication, and has always been one of the main topics of systemic functional linguists [5-7]. As one of the main types of educational discourse, textbook discourse has undergone great changes in its morphology, and its multimodality has 
attracted the attention of linguists [8]. As an educational tool and educational material, English textbook is not only an important part of the curriculum, but also the carrier of curriculum implementation. This study focuses on the the pilot comparative study of multimodal characteristics towards science education distributed by science education of biological quality, science education of ecological environment quality, science education of hazard prevention and cognition education of science and technology frontier in English textbooks of senior high school published by PEP (People's Education Press), BNUPH (Beijing Normal University Publishing House) and FLTRP (Foreign Language Teaching and Research Press); tries to investigate the attitude of teachers towards science education; and explore the more scientific ways of meta-meaning construction in the discourse of science education from the perspective of multimodality.

It is one of the important education contents in the post epidemic era to improve the scientific cognitive ability and scientific literacy ability of teenagers. The cultivation of scientific literacy needs to be realized through the main way of science education. However, the discourse research of science education in English textbooks of senior high school from the perspective of multimodality is not satisfactory. This not only affects the improvement of students' and teachers' scientific literacy, hinder the inherit of science education, but also it does not match the social situation of post epidemic era and multimodal society. So it is urgent to analyze the discourse and form a common understanding towards science education, such as contents, integration forms, meaning construction, relation between image and text; to investigate the attitude of English teachers from senior high school towards science education in English textbooks of senior high school from the perspective of multimodality. The theoretical basis of multimodal discourse analysis is mainly based on VG, relation of image and text. This study is the multi-modal discourse analysis of science education in English textbooks of senior high school. The purpose of this study is to study the content distribution and proportion of science education in English textbooks of senior high school, and the transmission function of two main modals, image and text, and finally explore the effects of the two main modals of image and text for teachers' teaching and students' learning. Therefore, this study adopts three theories of VG [9, 10], relation of image and text, and Cheng Xiaotang's textbook analysis theory [11] as the theoretical basis for the research.

Because the existing research on science education in English textbooks of senior high school mostly analyzes several discourse of science, and seldom involves the comparison of multiple versions and the questionnaire survey to collect the attitude of teachers of basic education. As a consequence, this study mainly explores the following three research problems: (1) What are the characteristics of science education, namely, science education of biological quality, ecological environment quality, hazard prevention and cognition education of science and technology frontier in integration forms and proportion from the perspective of multimodality in English textbooks of senior high school? (2) What are the cognition, attitude and preference of students, teachers and experts towards science education in English textbooks of senior high school under the reform of basic English teaching? (3) What are the problems of science education in English textbooks of senior high school under the compilation reform of English textbooks for basic education, and how to improve it?

A scientific research results need to form a comprehensive understanding on the core concepts. Science education and scientific literacy are two similar concepts.

Science education is aimed at imparting natural science knowledge, cultivating scientific spirit, developing the understanding of objective world law and improving the ability to transform the material world. According to the classification of science education classified by Ministry of National Education in Turkey, it is divided into seven categories [12], including knowledge, skills, perception, science, technology, society and environmental learning fields. According to the classification of science education classified by scholars in China, it is divided into three categories [13, 14], including knowledge of science, scientific method and scientific spirit, as shown in Table 1.

Scientific literacy is one of the important contents of core literacy. It was not until the formulation of the American 2061 plan in 1985 that a clear explanation was made of the abilities or skills that people with scientific literacy should have. According to the classification of scientific literacy classified by PISA, it is divided into six categories, including safety and health, natural resources, environmental quality, hazard prevention and technology frontier in personal situation, national or regional situation and global situation, as shown in Table 2.

This study analyzes the contents, integration forms, meaning construction, relation between image and text of science education and investigates the attitude of textbooks of senior high school. Taking three versions of science education distributed by science education of biological quality, science education of ecological environment quality, science education of hazard prevention and cognition education of science and technology frontier according to content of teaching in compulsory English textbooks of senior high school published by PEP, BNUPH and FLTRP, and 228 questionnaires from English teachers distributed in seven different urban areas in Henan Province, China towards science education in English textbooks of senior high school. Based on the content of science education in English textbooks of senior high school and the attitude of English teachers to science education, this study puts forward some suggestions on how to further improve the multimodal meaning presentation of science education in English textbooks of senior high school from the perspective of multimodality in systemic functional linguistics.

Science education should be an educational activity with science and the cultivation of people's scientific literacy as the core [15]. 
Table 1. Classification of Science Education

\begin{tabular}{ll}
\hline Scholars or Organization & Classification \\
\hline Ministry of National & Knowledge (biology and life, matter and change, physical, earth and universe), skills (scientific process skills and life skills), \\
Education (Turkey) & perception (behavior, motivation, values and responsibility), science, technology, society and environmental learning fields. \\
Yan Wang, Haiyan Yi & $\begin{array}{l}\text { Scientific knowledge (the life world, the material world and the earth and the universe), scientific method (observation, } \\
\text { classification, inference, comparison, hypothesis and experiment), scientific spirit (doubt and criticism, truth-seeking, } \\
\text { (China) }\end{array}$ \\
enterprising exploration, pioneering and innovative, strict and cautious, unremitting pursuit and pleasure in knowledge).
\end{tabular}

(Source: Classification of Science Education Classified by Ministry of National Education 2017 and Scholars in China)

Table 2. Classification of Scientific Literacy.

\begin{tabular}{ll}
\hline Scholars or Organization & Classification \\
\hline PISA 2018 & $\begin{array}{l}\text { Health and safety, natural resources, environmental quality, hazard prevention and technology frontier in personal situation, } \\
\text { national or regional situation and global situation. }\end{array}$ \\
\hline
\end{tabular}

(Source: Classification of Scientific Literacy Classified by PISA 2018)

The researcher classified science education as following four categories, namely, science education of biological quality, science education of ecological environment quality, science education of hazard prevention and cognition education of science and technology frontier according to teaching content combined with Classification of Science Education Classified by Ministry of National Education 2017 and Scholars in China, and Classification of Scientific Literacy Classified by PISA 2018, as shown in Table 3.

Table 3. Classification of Science Education in Study.

\begin{tabular}{ll}
\hline Classification & Definition \\
\hline Science education of biological quality & $\begin{array}{l}\text { Maintaining personal life and health, disease control and the spread of epidemic infectious diseases and } \\
\text { infectious diseases. }\end{array}$ \\
$\begin{array}{l}\text { Science education of ecological } \\
\text { environment quality }\end{array}$ & $\begin{array}{l}\text { Personal environmental protection behavior, environmental impact, biodiversity, biological environment } \\
\text { science education of hazard prevention }\end{array}$ \\
$\begin{array}{l}\text { The risk assessment of personal life style, the defense of instantaneous hazards } \\
\text { Cognition education of science and }\end{array}$ & $\begin{array}{l}\text { Hobbies, technology, music and sports activities of individuals in science; the genetic transformation and health } \\
\text { technology of the country; and space exploration, the origin and structure of the universe. }\end{array}$ \\
\hline
\end{tabular}

\section{Research Design}

\subsection{Research Objectives}

The research objectives are following:

To compare the multimodal characteristics of science education in English textbooks of senior high school published by PEP, BNUPH and FLTRP;

To investigate the attitude of English teachers from senior high school towards science education;

To puts forward some suggestions on how to further improve the multimodal meaning presentation of science education in English textbooks of senior high school from the perspective of multimodality.

And the researcher employed descriptive statistics including correlations, frequency, percentage, mean and standard deviation to explain details of demographic profiles of the respondents and behavior.

\subsection{Research Content}

\subsubsection{Multimodal Analysis of Science Education in English Textbooks}

The research introduces the classification of science education and integration forms classified by other scholars, confirms the classification of them in this study, and collects information to analyze the contents distribution, proportion, integration forms, meaning construction, relation between text and image.

\subsubsection{Attitude of English Teachers Towards Science Education}

The research designs a questionnaire survey for English teachers, and tries to understand the attitude of English teachers towards science education in English textbooks of senior high school.

\subsection{Research Subjects}

This research focuses on internal characteristics of science education and external characteristics of teachers' attitudes towards science education in English textbooks of senior high school published by PEP, BNUPH and FLTRP.

\subsection{Research Methods}

Qualitative data obtained from science education in English textbooks of senior high school by using content analysis; quantitative data obtained from survey questionnaires will be collected by online technology, deleted results with missing values in the questionnaire and coded in software Excel, calculated frequency, percentage, mean and standard deviation by using descriptive statistics to analyze and explain personal profiles of the respondents, using correlation analysis to test whether the attention towards science education in English textbooks of senior high school is related to these basic information. 
This research designed as a mixed method research using qualitative and quantitative method. The researcher uses content analysis to collect qualitative data from three versions English textbooks of senior high school published by PEP, BNUPH and FLTRP and uses survey questionnaire to collect data from the English teachers.

\subsection{Research Hypothesis}

Twelve hypotheses have been set for study purpose. All these are under the five dimensions of attitude toward content of science education (1 hypothesis), integration form of science education ( 1 hypothesis), individuals respondents (7 hypotheses), attitude of English teachers towards science education in teaching competence ( 2 hypotheses), attitude of English teachers to student's preference toward science education (1 hypothesis ).

H1: There are fewer science education in three versions English textbooks of senior high school.

$\mathrm{H} 2$ : Integration forms of science education are single in English textbooks of senior high school.

H3: There is less positive correlation between the teacher with different gender and the attention of science education in English textbooks.

H4: There is less positive correlation between the teacher who have ages and the attention of science education in English textbooks.

H5: The older the English teachers are, the more likely they are not concerned about the content of science education in English textbooks.

H6: There is less positive correlation between the teacher with the situation of front-line teachers and the attention of science education in English textbooks.

H7: There is less positive correlation between the teacher with the different situation of urban distribution and the attention of science education in English textbooks.

H8: There is less positive correlation between the teacher taught the different grade and the attention of science education in English textbooks.

H9: There is less positive correlation between the teacher who have different years of teaching and the attention of science education in English textbooks.

H10: English teachers of senior high school have mature understanding of science education.

H11: English teachers do complete systematic way in their teaching process of science education in English textbooks of senior high school.

H12: English teachers think students prefer to study science education than other contents by multimodality.

\subsection{Data Collecting Method}

The methods to collect data are following:

To classified science education and integration forms of science education in English textbooks of senior high school published by PEP, BNUPH and FLTRP;

To design the questionnaire survey of teachers on platform of questionnaire collecting online technology; and carry out to the English teachers on attitude towards science education from the perspective of multimodality in English textbooks of senior high school;

To collect the data and data analysis;

The researcher classified science education as following four categories, namely, science education of biological quality, science education of ecological environment quality, science education of hazard prevention and cognition education of science and technology frontier according to teaching content; and classified integration forms of science education as seven categories, namely, "text + image", "text + audio", "image + audio", "text + image + audio", "text", "image", "audio" according to classification of the transmutation factors of multimodal discourse meaning [16]. And the design of teachers' questionnaire using Likert scale (Level 5) includes 6 parts mainly: the first is basic information survey of the participants; the second is the English teachers' attitude towards necessity of science education in English textbooks of senior high school; the third is English teachers' attitude towards the content of science education in English textbooks of senior high school; the forth is English teachers' attitude towards the integration forms of science education in English textbooks of senior high school; the fifth is English teachers' attitude towards content and integration forms of science education that students will prefer; the sixth is English teachers' attitude towards their teaching competence of using multimodality to the science education of English textbooks in senior high school in the process of actual teaching.

Part 1. Basic personal information of gender, age group, front line teachers, urban distribution, grade, teaching experience;

Part 2. Questions related to necessity of science education in English textbooks of senior high school and a total of 4 questions;

Part 3. Questions related to content of science education in English textbooks of senior high school and a total of 4 questions;

Part 4. Questions related to integration forms of science education in English textbooks of senior high school and a total of 5 questions;

Part 5. Questions related to English teachers' attitude towards content and integration forms of science education that students will prefer and a total of 3 questions;

Part 6. Questions related to teaching competence of using multimodality to the science education of English textbooks in senior high school and a total of 4 questions;

There are 20 single choice questions related to the attitude about science education in the English textbook of senior high school that English teachers pay attention to or have used using 5 scale of Likert's scale concept to investigate from part 2 to part 6, and the principle of scoring including "1"refers to "strongly disagree", " 2 " refers to "disagree", "3" refers to "not sure", "4" refers to "quite agree", "5" refers to "strongly agree".

\section{Data Analysis and Discussion}

According to Cheng Xiaotang's textbook analysis theory, 
following will be analyze the data results through internal evaluation and external evaluation. Internal evaluation is the analysis and evaluation of the guiding ideology of textbooks, the components of textbooks, the arrangement of textbooks' contents, the authenticity of textbooks' language materials, the design of textbooks and the evaluation of textbooks; external evaluation is to evaluate textbooks for a certain user group.

\subsection{Internal Evaluation}

Table 4. Characteristics of science education in textbook of PEP, BNUPH, FLTRP.

\begin{tabular}{|c|c|c|c|c|c|c|c|c|c|c|}
\hline Content & Version & Text & Image & Audio & $\begin{array}{l}\text { Text }+ \\
\text { image }\end{array}$ & Text + audio & $\begin{array}{l}\text { Image }+ \\
\text { audio }\end{array}$ & $\begin{array}{l}\text { Text+image }+ \\
\text { audio }\end{array}$ & Total & Percent \\
\hline \multirow{3}{*}{$\begin{array}{l}\text { Science education of } \\
\text { biological quality }\end{array}$} & PEP & 8 & 1 & 0 & 8 & 0 & 0 & 1 & 15 & $12.20 \%$ \\
\hline & BNUPH & 34 & 0 & 0 & 5 & 4 & 0 & 0 & 43 & $35.83 \%$ \\
\hline & FLTRP & 46 & 0 & 0 & 5 & 3 & 0 & 1 & 55 & $26.32 \%$ \\
\hline \multirow{2}{*}{$\begin{array}{l}\text { Science education of } \\
\text { ecological environment } \\
\text { quality }\end{array}$} & PEP & 1 & 0 & 0 & 2 & 1 & 0 & 0 & 4 & $3.25 \%$ \\
\hline & BNUPH & 13 & 0 & 0 & 5 & 1 & 0 & 2 & 21 & $17.50 \%$ \\
\hline \multirow{3}{*}{$\begin{array}{l}\text { Science education of } \\
\text { hazard prevention }\end{array}$} & PEP & 10 & 0 & 0 & 4 & 3 & 0 & 2 & 19 & $15.45 \%$ \\
\hline & BNUPH & 7 & 0 & 0 & 3 & 0 & 0 & 0 & 10 & $8.33 \%$ \\
\hline & FLTRP & 13 & 0 & 0 & 4 & 4 & 0 & 1 & 22 & $10.53 \%$ \\
\hline \multirow{3}{*}{$\begin{array}{l}\text { Cognition education of } \\
\text { science and technology } \\
\text { Frontier }\end{array}$} & PEP & 48 & 3 & 0 & 30 & 2 & 0 & 4 & 85 & $69.11 \%$ \\
\hline & BNUPH & 34 & 0 & 0 & 11 & 1 & 0 & 0 & 46 & $38.33 \%$ \\
\hline & FLTRP & 83 & 0 & 0 & 15 & 7 & 0 & 1 & 104 & $49.76 \%$ \\
\hline
\end{tabular}

Information from Table 4 revealed that the frequency and percent of content distribution, integration forms towards science education. In terms of the content distribution of science education, the PEP, BNUPH and FLTRP share the same characteristics in the distribution of science education, that is, they are relatively concentrated in the cognition education of science and technology frontier. Specifically, proportions of cognition education of science and technology frontier in the total science education of the corresponding versions are $69.11 \%, 38.33 \%$ and $49.76 \%$, respectively. In English textbooks of senior high school published by PEP, science education of hazard prevention accounts for the second place, accounting for $15.45 \%$; science education of biological quality accounts for $12.20 \%$; and science education of ecological environment quality accounts for $3.25 \%$. In English textbooks of senior high school published by BNUPH, the second is the science education of biological quality, accounting for $35.83 \%$; the third is the science education of ecological environment quality, with the proportion of $17.50 \%$; and finally, science education of hazard prevention, with the proportion of $8.33 \%$. In English textbooks of senior high school published by FLTRP, the second is the science education of biological quality, accounting for $26.32 \%$; the third is the science education of ecological environment quality, with the proportion of $13.40 \%$; last is the science education of hazard prevention, with the proportion of $10.53 \%$. The distribution of science education content is uneven, and the degree of systematization is not enough. Because of the knowledge characteristics of textbooks, the integration forms of science education in English textbooks of senior high school published by PEP, BNUPH and FLTRP is mainly based on the single modal of text. In other words, the present situation of the multi-modal presentation of science education needs to be improved. In the multimodal presentation of textbooks, "text + image" is commonly used. Among them, the most important thing to do is that to pay attention to the arrangement and application of "image + audio" and "text + image + audio".

Table 5. Representational meaning of science education of biological quality.

\begin{tabular}{lll}
\hline & Narrative representation & Conceptional representation \\
\hline PEP & $5(9.80 \%)$ & $2(3.92 \%)$ \\
BNUPH & $5(19.23 \%)$ & $0(0.00 \%)$ \\
FLTRP & $3(9.68 \%)$ & $2(6.45 \%)$ \\
\hline
\end{tabular}

Table 5 shows that the frequency and proportion of representational meaning towards science education of biological quality in English textbooks of senior high school. It can be found that the image frequency of NR in English textbooks of senior high school published by PEP accounts for $9.80 \%$ in science education, while the frequency of CR accounts for $3.92 \%$. The image frequency of NR in English textbooks of senior high school published by BNUPH accounts for $19.23 \%$ in science education, while the frequency of CR is 0 . The image frequency of NR in English textbooks of senior high school published by FLTRP accounts for $9.68 \%$, while the frequency of CR accounts for $6.45 \%$. The three versions of science education of biological quality, are using the narrative representation to arrange. The frequency of NR (accounting for 19.23\%) in BNUPH is sharply higher than CR (accounting for $0.00 \%$ ) compared with other two versions, PEP (accounting for 9.80\%) and FLTRP (accounting for 9.68\%). According to VG proposed by Kress \& van Leeuwen, narrative representation is the description of events or activities. As a consequence, it can be found that it mainly use the descriptive image to describe or deliver the science education. 
Table 6. Frequency of NR of science education of biological quality.

\begin{tabular}{llll}
\hline & Action process & Reactional process & Speech and mental process \\
\hline PEP & $0(0.00 \%)$ & $3(5.88 \%)$ & $2(3.92 \%)$ \\
BNUPH & $3(11.54 \%)$ & $2(7.69 \%)$ & $0(0.00 \%)$ \\
FLTRP & $1(3.23 \%)$ & $2(6.45 \%)$ & $0(0.00 \%)$ \\
\hline
\end{tabular}

It can be seen from the table 6 that in the process of narrative representation of science education of biological quality, the proportion of action process images in English textbooks of senior high school published by PEP accounts for $0.00 \%$, images of reactional process accounts for $5.88 \%$, and the images of speech mental process accounts for $3.92 \%$; the proportion of action process images in English textbooks of senior high school published by BNUPH accounts for $11.54 \%$, images of reaction process accounts for $7.69 \%$, the image of speech and mental process accounts for $0.00 \%$; the proportion of action process images in English textbooks of senior high school published by FLTRP for 3.23\%, the image of reaction process accounts for $6.45 \%$, and the image of speech and mental process accounts for $0.00 \%$. It can be seen that in the three versions of English textbooks of senior high school, the images are mainly action process and reaction process, but the PEP also involves some images of science education of biological quality in the speech and mental process.

Table 7. Representational meaning of science education of ecological environment quality.

\begin{tabular}{lll}
\hline & Narrative representation & Conceptional representation \\
\hline PEP & $0(0.00 \%)$ & $2(3.92 \%)$ \\
BNUPH & $2(7.69 \%)$ & $5(19.23 \%)$ \\
FLTRP & $3(9.68 \%)$ & $1(3.23 \%)$ \\
\hline
\end{tabular}

Table 7 shows that the frequency and proportion of representational meaning towards science education of ecological environment quality in three versions English textbooks of senior high school. It can be found that the distribution of NR and CR in science education of ecological environment quality is different from science education of biological quality. In science education of ecological environment quality, NR (accounting for $0.00 \%, 7.69 \%$ respectively) in PEP and BNUPH is lower than CR, however, NR (accounting for 9.68\%) in FLTRP is higher than CR. In other words, English textbooks of senior high school published by FLTRP pay more attention to illustrate science education of ecological environment quality than PEP and BNUPH. PEP and BNUPH pay more attention to a stable process because Kress and van Leeuwen believe that conceptual process is a representational process which is more stable than narrative process in event, space and structure.

Table 8. Frequency of NR of science education of ecological environment quality.

\begin{tabular}{llll}
\hline Action process & $\begin{array}{l}\text { Reactional } \\
\text { process }\end{array}$ & $\begin{array}{l}\text { Speech and } \\
\text { mental process }\end{array}$ \\
\hline PEP & $0(0.00 \%)$ & $0(0.00 \%)$ & $0(0.00 \%)$ \\
BNUPH & $1(3.85 \%)$ & $1(3.85 \%)$ & $0(0.00 \%)$ \\
FLTRP & $1(3.23 \%)$ & $2(6.45 \%)$ & $0(0.00 \%)$ \\
\hline
\end{tabular}

As can be seen from table 8 , in terms of image distribution of science education of ecological environment quality, the narrative representation images with vector characteristics in English textbooks of senior high school published by PEP are deficient relatively, focusing on CR; in English textbooks of senior high school published by BNUPH, there are two images of NR, of which $3.85 \%$ are action process and $3.85 \%$ are reflection; in English textbooks of senior high school published by FLTRP, there are three images of NR, of which $3.23 \%$ are action process and $6.45 \%$ are reaction process.

Table 9. Representational meaning of science education of hazard prevention.

\begin{tabular}{lll}
\hline & Narrative representation & Conceptional representation \\
\hline PEP & $3(5.88 \%)$ & $4(7.84 \%)$ \\
BNUPH & $1(3.85 \%)$ & $2(7.69 \%)$ \\
FLTRP & $0(0.00 \%)$ & $5(16.13 \%)$ \\
\hline
\end{tabular}

Table 9 shows that the frequency and proportion of representational meaning towards science education of hazard prevention in three versions English textbooks of senior high school. It can be found that in the representational meaning of science education of hazard prevention corpus in English textbooks of senior high school, the image of PEP textbook presents meaning to readers through the process of NR. The reason is that most of the images in the textbook are intended to present information to students. NR is just to establish an action and reaction process with the readers with the vision of characters and participants. Compared with the process of CR, $\mathrm{NR}$ is the most easy way for readers to participate in the representation; however, the arrangement of this part of the English textbooks of senior high school published by BNUPH is more uniform than that of PEP and FLTRP, and both NR and $\mathrm{CR}$ are involved at the same time; English textbooks of senior high school published by FLTRP focuses more on CR, and it is just the opposite with English textbooks of senior high school published by PEP towards science education of hazard prevention corpus.

Table 10. Frequency of NR of science education of hazard prevention.

\begin{tabular}{llll}
\hline & Action process & $\begin{array}{l}\text { Reactional } \\
\text { process }\end{array}$ & $\begin{array}{l}\text { Speech and } \\
\text { mental process }\end{array}$ \\
\hline PEP & $2(3.92 \%)$ & $1(1.96 \%)$ & $0(0.00 \%)$ \\
BNUPH & $0(0.00 \%)$ & $1(3.85 \%)$ & $0(0.00 \%)$ \\
FLTRP & $0(0.00 \%)$ & $0(0.00 \%)$ & $0(0.00 \%)$ \\
\hline
\end{tabular}

As can be seen from table 10, in terms of image distribution of science education of hazard prevention, English textbooks of senior high school published by PEP focuses on NR, especially action process and reactional process. Images of action process accounts for $3.92 \%$, reactional process accounts for $1.96 \%$; in English textbooks of senior high school published by BNUPH, there is one image of NR, of which $3.85 \%$ are reflection process. 
Table 11. Representational meaning of cognition education of science and technology frontier.

\begin{tabular}{lll}
\hline & Narrative representation & Conceptional representation \\
\hline PEP & $22(43.14 \%)$ & $13(25.49 \%)$ \\
BNUPH & $5(19.23 \%)$ & $6(23.08 \%)$ \\
FLTRP & $6(19.35 \%)$ & $11(35.48 \%)$ \\
\hline
\end{tabular}

Table 11 shows that the frequency and proportion of representational meaning towards cognition education of science and technology frontier in three versions English textbooks of senior high school. The proportion of NR is $43.14 \%$ in PEP, CR is $25.49 \%$; the proportion of NR is $19.23 \%$ in BNUPH, CR is $23.08 \%$; the proportion of NR is $19.35 \%$ in FLTRP, CR is $35.48 \%$. It can be found that the frequency and proportion of NR in BNUPH and FLTRP are lower than CR except for PEP. In the distribution of representational meaning towards science education, the proportion of NR is higher than CR in PEP except for science education of ecological environment quality; the proportion of NR is lower than CR in BNUPH except for science education of biological quality; the proportion of NR is higher than CR in FLTRP except for science education of hazard prevention and cognition education of science and technology frontier.

Table 12. Frequency of NR of cognition education of science and technology frontier.

\begin{tabular}{llll}
\hline & Action process & $\begin{array}{l}\text { Reactional } \\
\text { process }\end{array}$ & $\begin{array}{l}\text { Speech and } \\
\text { mental process }\end{array}$ \\
\hline PEP & $6(11.76 \%)$ & $16(31.37 \%)$ & $0(0.00 \%)$ \\
BNUPH & $1(3.85 \%)$ & $4(15.38 \%)$ & $0(0.00 \%)$ \\
FLTRP & $2(6.45 \%)$ & $4(12.90 \%)$ & $0(0.00 \%)$ \\
\hline
\end{tabular}

It can be seen from table 12 that in the NR of English textbooks of senior high school published by PEP, the proportion of reaction process accounts for $31.37 \%$, and the proportion of action process accounts for $11.76 \%$; in the NR of English textbooks of senior high school published by BNUPH, the proportion of reaction process accounts for $3.85 \%$, and the proportion of action process accounts for 15.38\%; in the English textbooks of senior high school published by FLTRP, the proportion of reaction process and action process accounts for $6.45 \%$ and $12.90 \%$ respectively.

Table 13. Interactive meaning in science education of biological quality.

\begin{tabular}{lll}
\hline & Demand & Offer \\
\hline PEP & $0(0.00 \%)$ & $7(13.73 \%)$ \\
BNUPH & $1(3.85 \%)$ & $4(15.38 \%)$ \\
FLTRP & $0(0.00 \%)$ & $5(16.13 \%)$ \\
\hline
\end{tabular}

Table 13 shows that the frequency and proportion of interactive meaning towards science education of biological quality in three versions English textbooks of senior high school. It can be found that the frequency and proportion are concentrated on offer, more specifically, offer is at least five times the proportion of demand. The proportion of demand in PEP is $0.00 \%$, the proportion of offer is $13.73 \%$; the proportion of demand in BNUPH is $3.85 \%$, the proportion of offer is $15.38 \%$; the proportion of demand in FLTRP is $0.00 \%$, the proportion of offer is $16.13 \%$.
Table 14. Interactive meaning in science education of ecological environment quality.

\begin{tabular}{lll}
\hline & Demand & Offer \\
\hline PEP & $0(0.00 \%)$ & $2(3.92 \%)$ \\
BNUPH & $1(3.85 \%)$ & $6(23.08 \%)$ \\
FLTRP & $0(0.00 \%)$ & $4(12.90 \%)$ \\
\hline
\end{tabular}

Table 14 shows that the frequency and proportion of interactive meaning towards science education of ecological environment quality in three versions English textbooks of senior high school. It can be found that the characteristics of science education of ecological environment quality is similar to the distribution in science education of biological quality. In other words, it focuses on "offer" rather than "demand". The proportion of demand in PEP is $0.00 \%$, the proportion of offer is $3.92 \%$; the proportion of demand in $\mathrm{BNUPH}$ is $3.85 \%$, the proportion of offer is $23.08 \%$; the proportion of demand in FLTRP is $0.00 \%$, the proportion of offer is $12.90 \%$.

Table 15. Interactive meaning in science education of hazard prevention.

\begin{tabular}{lll}
\hline & Demand & Offer \\
\hline PEP & $0(0.00 \%)$ & $7(13.73 \%)$ \\
BNUPH & $0(0.00 \%)$ & $3(11.54 \%)$ \\
FLTRP & $0(0.00 \%)$ & $5(16.13 \%)$ \\
\hline
\end{tabular}

Table 15 shows that the frequency and proportion of interactive meaning towards science education of hazard prevention in three versions English textbooks of senior high school. It can be found that "offer" occupies the main corpus of image. The proportion of offer are $13.73 \%, 11.54 \%$ and $16.13 \%$.

Table 16. Interactive meaning in cognition education of science and technology frontier.

\begin{tabular}{lll}
\hline & Demand & Offer \\
\hline PEP & $14(27.45 \%)$ & $21(41.18 \%)$ \\
BNUPH & $3(11.54 \%)$ & $8(30.77 \%)$ \\
FLTRP & $2(6.45 \%)$ & $15(48.39 \%)$ \\
\hline
\end{tabular}

Table 16 shows that the frequency and proportion of interactive meaning towards cognition education of science and technology frontier in three versions English textbooks of senior high school. It can be found that the proportion of "offer" is more than "demand" from general perspective. The proportion of "demand" in PEP is $27.45 \%$, "offer" is $41.18 \%$; the proportion of "demand" in BNUPH is $11.54 \%$, "offer" is $30.77 \%$; the proportion of "demand" in FLTRP is $6.45 \%$, "offer" is $48.39 \%$.

Table 17. Interactive meaning in science education of biological quality.

\begin{tabular}{lllll}
\hline & Close & Medium & Long & Total \\
\hline PEP & $2(3.92 \%)$ & $1(1.96 \%)$ & $4(7.84 \%)$ & $7(13.73 \%)$ \\
BNUPH & $0(0.00 \%)$ & $2(7.69 \%)$ & $3(11.54 \%)$ & $5(19.23 \%)$ \\
FLTRP & $1(3.23 \%)$ & $0(0.00 \%)$ & $5(16.13 \%)$ & $6(19.35 \%)$ \\
\hline
\end{tabular}

Table 17 shows that the frequency and proportion of interactive meaning towards science education of biological quality in three versions English textbooks of senior high school. It can be found that the long social distance is main method of taking images, and the proportions of long social distance in PEP, BNUPH and FLTRP are $7.84 \%, 11.54 \%$ and $16.13 \%$ respectively. It is significantly more than the sum of 
close social distance and medium social distance.

Table 18. Interactive meaning in science education of ecological environment quality.

\begin{tabular}{lllll}
\hline & Close & Medium & Long & Total \\
\hline PEP & $0(0.00 \%)$ & $0(0.00 \%)$ & $2(3.92 \%)$ & $2(3.92 \%)$ \\
BNUPH & $1(3.85 \%)$ & $0(0.00 \%)$ & $6(23.08 \%)$ & $7(26.92 \%)$ \\
FLTRP & $1(3.23 \%)$ & $0(0.00 \%)$ & $3(14.29 \%)$ & $4(19.05 \%)$ \\
\hline
\end{tabular}

Table 18 shows that the frequency and proportion of interactive meaning towards science education of ecological environment quality in three versions English textbooks of senior high school. It can be found that the long social distance is main method of taking images, and the proportions of long social distance in PEP, BNUPH and FLTRP are 3.92\%, $23.08 \%$ and $14.29 \%$ respectively.

Table 19. Interactive meaning in science education of hazard prevention.

\begin{tabular}{lllll}
\hline & Close & Medium & Long & Total \\
\hline PEP & $0(0.00 \%)$ & $0(0.00 \%)$ & $7(13.73 \%)$ & $8(13.73 \%)$ \\
BNUPH & $0(0.00 \%)$ & $0(0.00 \%)$ & $3(11.54 \%)$ & $3(11.54 \%)$ \\
FLTRP & $0(0.00 \%)$ & $0(0.00 \%)$ & $5(16.13 \%)$ & $5(16.13 \%)$ \\
\hline
\end{tabular}

Table 19 shows that the frequency and proportion of interactive meaning towards science education of hazard prevention in three versions English textbooks of senior high school. It can be found that the long social distance is main method of taking images, and the proportions of long social distance in PEP, BNUPH and FLTRP are $13.73 \%, 11.54 \%$ and $16.13 \%$ respectively.

Table 20. Interactive meaning in cognition education of science and technology frontier

\begin{tabular}{lllll}
\hline & Close & Medium & Long & Total \\
\hline PEP & $12(23.53 \%)$ & $4(7.84 \%)$ & $19(37.25 \%)$ & $35(68.63 \%)$ \\
BNUPH & $1(3.85 \%)$ & $1(3.85 \%)$ & $9(34.62 \%)$ & $11(42.31 \%)$ \\
FLTRP & $2(6.45 \%)$ & $1(3.23 \%)$ & $13(41.94 \%)$ & $16(51.61 \%)$ \\
\hline
\end{tabular}

Table 20 shows that the frequency and proportion of interactive meaning towards cognition education of science and technology frontier in three versions English textbooks of senior high school. It can be found that the long social distance is main method of taking images, and the proportions of long social distance in PEP, BNUPH.

Table 21. Compositional meaning in science education of biological quality.

\begin{tabular}{|c|c|c|c|c|c|c|}
\hline & Bottom-left & Bottom-right & Top-left & Top-right & Center & Total \\
\hline PEP & $0(0.00 \%)$ & $5(9.80 \%)$ & $0(0.00 \%)$ & $0(0.00 \%)$ & $2(3.92 \%)$ & $7(13.73 \%)$ \\
\hline BNUPH & $0(0.00 \%)$ & $1(3.85 \%)$ & $1(3.85 \%)$ & $1(3.85 \%)$ & $2(7.69 \%)$ & $5(19.23 \%)$ \\
\hline FLTRP & $1(3.23 \%)$ & $3(9.68 \%)$ & $0(0.00 \%)$ & $1(3.23 \%)$ & $1(3.23 \%)$ & $6(19.35 \%)$ \\
\hline
\end{tabular}

Table 21 shows that the frequency and proportion of compositional meaning towards science education of biological quality in three versions English textbooks of senior high school. It can be found that the images situated in the part of bottom-right and center are more frequently than other, such as bottom-left, top-left, and top-right. The reason why the images in the center account for more proportion is that the images arranged in the central position are easier to attract the readers' attention; the lower left position represents the real and known information. The reason why the proportion of images stations in the lower left position is more than that in the lower left position is that the real and known information guides the reader to the unknown and new information in the text on the right.

Table 22. Compositional meaning in science education of ecological environment quality.

\begin{tabular}{|c|c|c|c|c|c|c|}
\hline & Bottom-left & Bottom-right & Top-left & Top-right & Center & Total \\
\hline PEP & $0(0.00 \%)$ & $1(1.96 \%)$ & $0(0.00 \%)$ & $0(0.00 \%)$ & $1(1.96 \%)$ & $2(3.92 \%)$ \\
\hline BNUPH & $0(0.00 \%)$ & $0(0.00 \%)$ & $2(7.69 \%)$ & $2(7.69 \%)$ & $3(11.54 \%)$ & $7(26.92 \%)$ \\
\hline FLTRP & $0(0.00 \%)$ & $1(3.23 \%)$ & $0(0.00 \%)$ & $2(6.45 \%)$ & $1(3.23 \%)$ & $4(12.90 \%)$ \\
\hline
\end{tabular}

Table 22 shows that the frequency and proportion of compositional meaning towards ecological environment quality in three versions English textbooks of senior high school. It can be found that the images situated in the part of top-right and center are more frequently than other, such as bottom-left, top-left, and bottom-right.

Table 23. Compositional meaning in science education of hazard prevention.

\begin{tabular}{|c|c|c|c|c|c|c|}
\hline & Bottom-left & Bottom-right & Top-left & Top-right & Center & Total \\
\hline PEP & $2(3.92 \%)$ & $4(7.84 \%)$ & $0(0.00 \%)$ & $0(0.00 \%)$ & $1(1.96 \%)$ & $7(13.73 \%)$ \\
\hline BNUPH & $0(0.00 \%)$ & $1(3.85 \%)$ & $0(0.00 \%)$ & $2(7.69 \%)$ & $0(0.00 \%)$ & $3(11.54 \%)$ \\
\hline FLTRP & $0(0.00 \%)$ & $0(0.00 \%)$ & $0(0.00 \%)$ & $4(12.90 \%)$ & $1(3.23 \%)$ & $5(16.13 \%)$ \\
\hline
\end{tabular}

Table 23 shows that the frequency and proportion of compositional meaning towards ecological environment quality in three versions English textbooks of senior high school. It can be found that the images situated in the part of top-right and bottom-right are more frequently than other, such as bottom-left, top-left, and center. 
Table 24. Compositional meaning in cognition education of science and technology frontier

\begin{tabular}{llllll}
\hline & Bottom-left & Bottom-right & Top-left & Top-right & Center \\
\hline PEP & $4(7.84 \%)$ & $1(1.96 \%)$ & $7(13.73 \%)$ & $13(25.49 \%)$ & $10(19.61 \%)$ \\
BNUPH & $0(0.00 \%)$ & $0(0.00 \%)$ & $2(7.69 \%)$ & $6(23.08 \%)$ & $3(11.54 \%)$ \\
FLTRP & $1(3.23 \%)$ & $3(9.68 \%)$ & $1(3.23 \%)$ & $5(16.13 \%)$ & $6(19.35 \%)$ \\
\hline
\end{tabular}

Table 24 shows that the frequency and proportion of compositional meaning towards cognition education of science and technology frontier in three versions English textbooks of senior high school. It can be found that the images situated in the part of top-right and center are more frequently than other, such as bottom-left, top-left, and bottom-right.

Deep Characteristics of Science Education Based on Relation of Image and Text

According to Martine \& Salway's theory of the relationship between images and texts, the status of images and texts can be divided into two types: equal relation and unequal relation.

Table 25. Relation between images and texts of science education.

\begin{tabular}{llll}
\hline & Equal Relation & Unequal Relation \\
\hline & $\begin{array}{l}\text { Independent relation between text } \\
\text { \& image }\end{array}$ & $\begin{array}{l}\text { Complementary relation between } \\
\text { text \& image }\end{array}$ & Image subordinate to text \\
\hline PEP & $11(21.57 \%)$ & $3(5.88 \%)$ & $33(64.71 \%)$ \\
BNUPH & $2(7.69 \%)$ & $4(15.38 \%)$ & $20(76.92 \%)$ \\
FLTRP & $9(26.47 \%)$ & $2(5.88 \%)$ & $20(58.82 \%)$ \\
\hline
\end{tabular}

Table 25 shows that the proportion of relation between images and texts in science education in PEP, BNUPH and FLTRP. It can be found that the proportion of unequal relation is more richer than equal relation in three versions of English textbooks. The proportion of image subordinate to text in PEP BNUPH and FLTRP accounts for $64.71 \%, 76.92 \%, 58.82 \%$ respectively. However, the proportion of text subordinate to image is sharply scarce. The proportion of independent relation between text and image in PEP BNUPH and FLTRP accounts for $21.57 \%, 7.69 \%, 26.47 \%$ respectively; complementary relation between text and image in PEP BNUPH and FLTRP accounts for $5.88 \%, 15.38 \%, 5.88 \%$ respectively.

In the distribution of science education, the similarity lies in that the three versions of English textbooks of senior high school mainly focus on cognition education of science and technology frontier, especially the hobbies, technology, music and sports activities of individuals in science. However, some contents from broader view, such as the national gene transformation and health technology, space exploration, the origin and structure of the universe are relatively scarce. In the integration forms of science education, it is mainly based on the single modal of text. In other words, the present situation of the multimodal presentation of science education needs to be improved. In the multimodal presentation of textbooks, "text + image" is commonly used. Among them, the most important thing to do is that to pay attention to the arrangement and application of "image + audio" and "text + image + audio". In the representational meaning of images towards science education, NR is more than CR in three versions English textbooks in senior high school; in the interactive meaning of images towards science education, offer is more than demand in three versions English textbooks in senior high school, and the image focuses on long distance; in the compositional meaning of images towards science education, the images of science education of biological quality are concentrated on the situation of bottom-right and center; science education of ecological environment quality are concentrated on the situation of top-right and center; science education of hazard prevention are concentrated on the situation of top-right and bottom-right; cognition education of science and technology frontier are concentrated on the situation of top-right and center. In the relation of image and text, the characteristics focus on image subordinate to text in three versions English textbooks in senior high school. And the content of science education in the three versions of English textbooks of senior high school in a specific unit is not strong enough, scattered in some units. This feature has some limitations for students and teachers to extract, and requires teachers' cognitive ability of science education.

\subsection{External Evaluation}

A total of 228 teachers from Anyang, Luoyang, Luohe, Xuchang were investigated. The distribution is as follows:

Table 26. Basic information of teachers.

\begin{tabular}{llll}
\hline Classification & & Frequency & Valid percent \\
\hline \multirow{2}{*}{ Gender } & Male & 35 & $15.4 \%$ \\
& Female & 193 & $84.6 \%$ \\
& $<30$ & 35 & $15.4 \%$ \\
Age group & $30 \sim 40$ & 123 & $53.9 \%$ \\
& $40 \sim 50$ & 49 & $21.5 \%$ \\
Front line & $>50$ & 21 & $9.2 \%$ \\
teachers & No & 2 & $0.9 \%$ \\
& Yes & 226 & $99.1 \%$ \\
& Anyang, Anyang & 19 & $8.3 \%$ \\
Urban & Luolong, Luoyang & 95 & $41.7 \%$ \\
distribution & Yanshi, Luoyang & 29 & $12.7 \%$ \\
& Yiyang, Luoyang & 11 & $4.8 \%$ \\
& Yancheng, Luohe & 12 & $5.3 \%$ \\
& Jian'an, Xuchang & 39 & $17.1 \%$ \\
Total & Xiangcheng, Xuchang & 23 & $10.1 \%$ \\
Grade & Senior 1 & 85 & $37.3 \%$ \\
& Senior 2 & 64 & $28.1 \%$ \\
experience & Senior 3 & 79 & $34.6 \%$ \\
& $1 \sim 5$ years & 35 & $15.4 \%$ \\
& 5 10 years & 62 & $27.2 \%$ \\
& 10 15 years & 31 & $13.6 \%$ \\
& 228 & 100 & $43.9 \%$ \\
\hline
\end{tabular}


It can be seen from the table 26 that the teachers participating in the questionnaire survey are distributed in different genders, age groups, front line teachers, urban distributions, grades, teaching experiences. The reliability and validity of the questionnaire are analyzed to judge whether the questionnaire reaches the credibility and good validity, so as to further analyze. Reliability test refers to the reliability test of questionnaire, which is vital to us researchers in the analyzing process of questionnaire survey results.

Table 27. Reliability statistics.

\begin{tabular}{ll}
\hline Reliability statistics \\
\hline Cronbach's Alpha & N of Items \\
\hline .949 & 20 \\
\hline
\end{tabular}

According to the table 27 above, Cronbach alpha is 0.949 $(0.949>0.9)$. According to Cronbach alpha of reliability statistics, the scale has good reliability.

Table 28. KMO and Bartlett's test.

\begin{tabular}{lll}
\hline \multicolumn{3}{l}{ KMO and Bartlett's Test } \\
\hline \multicolumn{3}{l}{ Kaiser-Meyer-Olkin Measure of Sampling Adequacy. } \\
& Approx. Chi-Square & .932 \\
Bartlett's test of sphericity & df & 3471.676 \\
& Sig. & 190 \\
& .000 \\
\hline
\end{tabular}

The validity of the questionnaire refers to the validity of the questionnaire, that is, whether the design of the questionnaire can achieve the research purpose. The results of validity are as
Table 28, the Kaiser-Meyer-Olkin Measure of Sampling Adequacy is $0.932(0.932>0.9)$. According to the provisions of validity, the validity of the questionnaire is quite good, that is, the questionnaire is effective. $\mathrm{P}=0.000(0.000<0.001))$, that is to say, the significance level was reached.

Part 1 Correlation analysis of basic information and attention (total score)

There are many factors influencing the formation of attitude. For English teachers of senior high school, whether gender, age, location and teaching age are closely related to and even have an impact on their attitude towards science education remains to be explored.

Table 29. Tests of normality.

\begin{tabular}{lllllll}
\hline & \multicolumn{3}{l}{ Kolmogorov-Smirnova } & \multicolumn{4}{l}{ Shapiro-Wilk } \\
\cline { 2 - 7 } & Statistic & df & Sig. & Statistic & df & Sig. \\
\hline Total score & .188 & 228 & .000 & .827 & 228 & .000 \\
\hline
\end{tabular}

a. Lilliefors Significance Correction

It can be seen from table 29 that the $\mathrm{P}=0.000<0.05$, indicating that there is a difference with the normal distribution, so the normal distribution is not satisfied. There are three kinds of correlation analysis: Pearson correlation analysis, Spearman correlation analysis and Kendall correlation analysis. And each of the three kinds of correlation analysis has its own limitations. When the data does not meet the normal distribution, Spearman correlation coefficient or Kendall correlation coefficient should be selected for analysis.

Table 30. Correlations between grouping variables and attention.

\begin{tabular}{|c|c|c|c|}
\hline & & & Total score \\
\hline \multirow{6}{*}{ Gender } & \multirow{3}{*}{ Kendall's tau_b } & Correlation coefficient & .077 \\
\hline & & Sig. (2-tailed) & .173 \\
\hline & & $\mathrm{N}$ & 228 \\
\hline & \multirow{3}{*}{ Spearman's rho } & Correlation coefficient & .090 \\
\hline & & Sig. (2-tailed) & .173 \\
\hline & & $\mathrm{N}$ & 228 \\
\hline \multirow{6}{*}{ Age Group } & \multirow[t]{2}{*}{ Kendall's tau_b } & Correlation coefficient & -.051 \\
\hline & & Sig. (2-tailed) & .328 \\
\hline & \multirow{4}{*}{ Spearman's rho } & $\mathrm{N}$ & 228 \\
\hline & & Correlation coefficient & -.068 \\
\hline & & Sig. (2-tailed) & .307 \\
\hline & & $\mathrm{N}$ & 228 \\
\hline \multirow{6}{*}{ First-Line Teachers } & \multirow[t]{2}{*}{ Kendall's tau_b } & Correlation coefficient & .000 \\
\hline & & Sig. (2-tailed) & .996 \\
\hline & \multirow{4}{*}{ Spearman's rho } & $\mathrm{N}$ & 228 \\
\hline & & Correlation coefficient & .000 \\
\hline & & Sig. (2-tailed) & .996 \\
\hline & & $\mathrm{N}$ & 228 \\
\hline \multirow{6}{*}{ Urban Distribution } & \multirow[t]{2}{*}{ Kendall's tau_b } & Correlation coefficient & .009 \\
\hline & & Sig. (2-tailed) & .856 \\
\hline & \multirow{4}{*}{ Spearman's rho } & $\mathrm{N}$ & 228 \\
\hline & & Correlation coefficient & .012 \\
\hline & & Sig. (2-tailed) & .859 \\
\hline & & $\mathrm{N}$ & 228 \\
\hline \multirow{6}{*}{ Grade } & \multirow[t]{2}{*}{ Kendall's tau_b } & Correlation coefficient & .057 \\
\hline & & Sig. (2-tailed) & .284 \\
\hline & \multirow{4}{*}{ Spearman's rho } & $\mathrm{N}$ & 228 \\
\hline & & Correlation coefficient & .072 \\
\hline & & Sig. (2-tailed) & .276 \\
\hline & & $\mathrm{N}$ & 228 \\
\hline
\end{tabular}




\begin{tabular}{|c|c|c|c|}
\hline & & & Total score \\
\hline \multirow{6}{*}{ Teaching Experience } & Kendall's tau_b & Correlation coefficient & -.009 \\
\hline & \multirow{5}{*}{ Spearman's rho } & Sig. (2-tailed) & .859 \\
\hline & & $\mathrm{N}$ & 228 \\
\hline & & Correlation coefficient & -.012 \\
\hline & & Sig. (2-tailed) & .854 \\
\hline & & $\mathrm{N}$ & 228 \\
\hline
\end{tabular}

According to table 30, the correlation of English teachers' total score to science education and their gender, ages, front-line teachers, urban distribution, grade, and teaching experience is less than 0.19 . Therefore, it can be seen that there is a very low positive correlation between English teachers' total score to science education and their gender, ages, front-line teachers, urban distribution, grade, and teaching experience. The research results from the test, therefore, accepted the Hypothesis 3 which stated that there is less positive correlation between the teacher with different gender and the attention of science education in English textbooks, Hypothesis 4 which stated that there is less positive correlation between the teacher who have ages and the attention of science education in English textbooks, Hypothesis 5 which stated that there is less positive correlation between the teacher with different gender and the attention of science education in English textbooks, Hypothesis 6 which stated that there is less positive correlation between the teacher with the situation of front-line teachers and the attention of science education in English textbooks, Hypothesis 7 which stated that there is less positive correlation between the teacher with the different situation of urban distribution and the attention of science education in English textbooks, Hypothesis 8 which stated that there is less positive correlation between the teacher taught the different grade and the attention of science education in English textbooks, and Hypothesis 9 which stated that there is less positive correlation between the teacher who have different years of teaching and the attention of science education in English textbooks.

Part 2 Necessity of science education

Table 31. Necessity of science education.

\begin{tabular}{|c|c|c|c|c|c|c|c|}
\hline \multicolumn{8}{|c|}{ Teacher Questionnaire Q8-Q11 } \\
\hline Qs & Mean & S. D. & Very disagree & Disagree & Not sure & Quite agree & Strongly agree \\
\hline Q8 & 4.67 & 0.602 & $0 \%$ & $1.8 \%$ & $1.8 \%$ & $24.1 \%$ & $72.4 \%$ \\
\hline Q9 & 4.53 & 0.788 & $0.9 \%$ & $3.5 \%$ & $2.6 \%$ & $28.1 \%$ & $64.9 \%$ \\
\hline Q10 & 4.74 & 0.530 & $0 \%$ & $0.9 \%$ & $1.8 \%$ & $19.7 \%$ & $77.6 \%$ \\
\hline Q11 & 4.71 & 0.588 & $0 \%$ & $1.3 \%$ & $3.1 \%$ & $18.4 \%$ & $77.2 \%$ \\
\hline
\end{tabular}

It can be seen from table 31 that $96.5 \%$ of English teachers from senior high school agree with the issue of " $Q 8$ I think it is necessary to include the content of science education in English textbooks of senior high school", 72.4\% strongly agree among them. Among the respondents, only $1.8 \%$ of English teachers from senior high school disagree. And the mean value is 4.67 , and the standard deviation is 0.602 , which is close to 0 , indicating that the respondents have low dispersion of opinions on this question. That is to say, to a large extent, it is necessary to include science education in English textbooks of senior high school. When asked whether agree the question, namely " $Q 9$ I think that the content of science education in English textbooks of senior high school is closely related to students' learning and future life", according to the data in the table above, $93 \%$ of the participating teachers agree, and $4.4 \%$ think it is not related to students' learning and life. On this question, the overall mean value is 4.53 , and the standard deviation is 0.788 , which is also very close to 0 . On the attitude of " $Q 10$ I think the content of science education in English textbooks of senior high school can be used as one of the important ways to cultivate students' international vision and inherit science and culture", $97.3 \%$ of the respondents agree and $0.9 \%$ disagree $($ mean $=4.74$, S.D. $=0.530)$, which indicates that the majority of the respondents agree on this issue. $95.6 \%$ agreed and $1.3 \%$ disagreed on the opinion, namely " $Q 11$ I think that teaching Chinese science education in the process of English teaching through senior high school would help cultivate students' patriotic enthusiasm and national pride" (mean=4.71, S.D.= 0.588).

Through the above table and detailed analysis, it can be seen that the vast majority of English teachers in senior high school have the same view on the necessity of science education in English textbooks of senior high school. They think that science education is closely related to students' learning and life, and it is necessary for science education to exist in English textbooks and English teaching of senior high school. In the process of learning, science education is conducive to the cultivation of their international vision and the inheritance of scientific culture, and then cultivate students' patriotic enthusiasm and national pride through science education.

Part 3 Content of science education 
Table 32. Content of science education.

\begin{tabular}{llllllll}
\hline \multicolumn{2}{l}{ Teacher Questionnaire Q12-Q15 } & & & & & \\
\hline Qs & Mean & S. D. & Very disagree & Disagree & Not sure & Quite agree & Strongly agree \\
\hline Q12 & 3.89 & 1.097 & $0.9 \%$ & $16.7 \%$ & $11.0 \%$ & $36.0 \%$ & $35.5 \%$ \\
Q13 & 4.64 & 0.609 & $0 \%$ & $0.9 \%$ & $4.4 \%$ & $24.1 \%$ & $70.6 \%$ \\
Q14 & 4.66 & 0.605 & $0 \%$ & $0.9 \%$ & $4.4 \%$ & $22.4 \%$ & $72.4 \%$ \\
Q15 & 4.61 & 0.665 & $0 \%$ & $1.8 \%$ & $4.8 \%$ & $24.1 \%$ & $69.3 \%$ \\
\hline
\end{tabular}

First of all, $71.5 \%$ of senior high school English teachers agree with the opinion, $17.6 \%$ of them are against it, namely, "Q12 I think the content and form of science education in English textbooks of senior high school is rich" (mean=3.89, S.D.=1.097). It can be seen that the opinions of the participants are relatively scattered under the assumption that the content and form of science education in English textbooks of senior high school are very rich. Nearly one fifth of English teachers in senior high school think that the content of science education in English textbooks of senior high school is not very rich. When asked what content should be taught in English textbooks of senior high school combined with the current situation and the needs of the epidemic situation, $94.8 \%$ think that biological science education, science information technology education and history of science and technology should be the important contents of science education for students of senior high school. Only $0.9 \%$ objected to this opinion. The standard deviation of the result about this problem is 0.609 , which shows that the dispersion degree is relatively low, that is, the attitude of most people is basically the same. Under the background of the "science and technology" era, science education has been attached great importance in almost every country. In the process of arranging the content of science education, national science education will inevitably account for a considerable proportion. Therefore, in Q140, namely, "I think there is a great need to increase the history of science and technology and science education of China in English textbooks of senior high school" (S.D.=0.605), and Q15, namely, "I think the basic English terminology expression and exercises of history about science and technology in China should be increased" (S.D. $=0.665)$, their attitudes are basically the same, respectively, with a low degree of dispersion. 94.8\% of English teachers of senior high school think that it is necessary to add the development history of science and technology and the content of science education about our country in the current English textbooks of senior high school, 0.9\% hold different opinions; 93.4\% think that the basic English terminology expression and exercises of history of science and technology about China should be added into the English textbooks of senior high school, and $1.8 \%$ are against it. Through the above table and analysis, it can be seen that the attitude of English teachers participating in this survey from senior high school is basically consistent in the part of science education content in English textbooks of senior high school.

Part 4 Presentation of science education

Thirdly, the presentation of science education in English textbooks of senior high school is analyzed, which includes four questions. And the results are as follows:

Table 33. Presentation of science education.

\begin{tabular}{|c|c|c|c|c|c|c|c|}
\hline \multicolumn{8}{|c|}{ Teacher questionnaire Q16-Q20 } \\
\hline Qs & Mean & S. D. & Very disagree & Disagree & Not sure & Quite agree & Strongly agree \\
\hline Q16 & 4.61 & 0.657 & $0 \%$ & $0.9 \%$ & $7.0 \%$ & $21.9 \%$ & $70.2 \%$ \\
\hline Q17 & 4.75 & 0.519 & $0 \%$ & $0.4 \%$ & $2.6 \%$ & $18.9 \%$ & $78.1 \%$ \\
\hline Q18 & 4.76 & 0.530 & $0 \%$ & $0.9 \%$ & $2.2 \%$ & $17.1 \%$ & $79.8 \%$ \\
\hline Q19 & 4.50 & 0.730 & $0 \%$ & $0.9 \%$ & $11.4 \%$ & $24.6 \%$ & $63.2 \%$ \\
\hline Q20 & 4.57 & 0.682 & $0 \%$ & $1.8 \%$ & $5.7 \%$ & $25.9 \%$ & $66.7 \%$ \\
\hline
\end{tabular}

First of all, 92.1\% of English teachers from senior high school agree with opinion and $0.9 \%$ of them are against it, namely, "Q16 I think the content of science education in English textbooks of senior high school should be presented in a systematic and systematic way" (mean $=4.61$, S.D. $=0.657)$. It can be seen that the opinions of the participants were less discrete. With the development of science and technology, the transmission of knowledge is no longer only relying on the traditional modal of words in a flat way, but instead of a more three-dimensional presentation to deepen students' understanding of knowledge. Therefore, when asked about the attitude of "Q17 I think that students are interested in multimodal presentation of science education, such as graphics, audio and video" (mean=4.75, S.D.=0.519), 97\% agreed and only $0.4 \%$ objected. Then, on the opinion of " $Q 18$
I think that the content of science education in English textbooks senior high school should be presented in multi-modal forms such as images, text, audio and video", $96.9 \%$ agree and $0.9 \%$ disagree. The standard deviation of this result is 0.530 , which is very close to 0 , indicating that the degree of dispersion is low and the consistency is good. On the attitude of self-assessment, namely, "Q19 I think that I have mastered the characteristics and forms of multi-modal scientific education content in English textbooks of senior high school", 87.8\% of English teachers senior high school think that they have mastered the characteristics and forms of science education, while $0.9 \%$ of them hold different opinions. The standard deviation of this problem is 0.730 , relatively large, but also very close to 0 . The reason for the relatively large results is that $11.4 \%$ of them are not sure whether they 
master their own characteristics and forms. The fundamental reason may be that there is no specific and systematic evaluation or test methods in the actual process of teaching. However, on the opinion of "Q20 I think that the use of multimodal presentation in English textbooks of senior high school is conducive to the introduction and discussion of science education content in classroom" (mean $=4.57$, S.D. $=0.682), 92.6 \%$ agree and $1.8 \%$ disagree with it. The result is also relatively high consistency and low dispersion.

Part 5 Students' preferences in teachers' opinion

Table 34. Attention of teachers to student's preference toward science education.

\begin{tabular}{|c|c|c|c|c|c|c|c|}
\hline \multicolumn{8}{|c|}{ Teacher questionnaire Q21-Q23 } \\
\hline Qs & Mean & S. D. & Very disagree & Disagree & Not sure & Quite agree & Strongly agree \\
\hline Q21 & 4.33 & 0.857 & $0 \%$ & $3.9 \%$ & $13.6 \%$ & $27.6 \%$ & $54.8 \%$ \\
\hline Q22 & 4.65 & 0.622 & $0 \%$ & $1.3 \%$ & $3.9 \%$ & $23.2 \%$ & $71.5 \%$ \\
\hline Q23 & 4.52 & 0.711 & $0 \%$ & $0.9 \%$ & $10.1 \%$ & $25.0 \%$ & $64.0 \%$ \\
\hline
\end{tabular}

It can be seen from the table 34 that $82.4 \%$ of teachers agree and $3.9 \%$ of students are more interested in science education than other contents in English textbooks of senior high school. The overall mean is 4.33 , and the standard deviation is 0.857 , close to 0 , indicating that most teachers have the same attitude on this question. As for students, $94.7 \%$ of English teachers in senior high school agree and $1.3 \%$ of them disagree on the opinion "Q22 I think the study of science education content in English textbooks of senior high school is conducive to the cultivation of their cross-cultural communication ability and scientific literacy ability". The mean is 4.65 and the standard deviation is 0.622 . On the opinion of " $Q 23$ I think that English science education will focus on the examination in the future", $89 \%$ of English teachers in senior high school agree with it, and $64.0 \%$ of them strongly agree. From the results of the above table and detailed analysis, it can be seen that the attitude of English teachers in senior high school to this item is basically the same.

Part 6 Teaching competence of teachers

Table 35. Attitude of teachers to their teaching competence toward science education.

\begin{tabular}{|c|c|c|c|c|c|c|c|}
\hline \multicolumn{8}{|c|}{ Teacher questionnaire Q24-Q27 } \\
\hline Qs & Mean & S. D. & Very disagree & Disagree & Not sure & Quite agree & Strongly agree \\
\hline Q24 & 4.60 & 0.667 & $0 \%$ & $1.8 \%$ & $4.8 \%$ & $25.4 \%$ & $68.0 \%$ \\
\hline Q25 & 4.49 & 0.705 & $0 \%$ & $0.4 \%$ & $11.0 \%$ & $28.1 \%$ & $60.5 \%$ \\
\hline Q26 & 4.61 & 0.657 & $0 \%$ & $1.8 \%$ & $4.4 \%$ & $24.6 \%$ & $69.3 \%$ \\
\hline Q27 & 4.51 & 0.680 & $0 \%$ & $0.9 \%$ & $7.9 \%$ & $30.7 \%$ & $60.5 \%$ \\
\hline
\end{tabular}

It can be seen from table 35 that $93.4 \%$ of English teachers agree with the opinion of "Q24 I think that English teachers should pay attention to guiding students to pay more attention to the contents of biological science education, science information technology education, and history of science and technology in senior high school English textbooks" (Mean=4.60, S.D.=0.667), 68.0\% strongly agree among them. On the opinion of "Q25 I think that I can accurately extract the information and content of science education in English textbooks of senior high school, and I can study and explore it with students", 88.60\% of English teachers in senior high school agree, and $60.5 \%$ of them strongly agree. And mean is 4.49 , the standard deviation is 0.705 , close to 0 , the degree of dispersion is not high, and the consensus is high. On the opinion of "Q26 I think that English teachers should pay attention to the combination of the current English textbooks of senior high school, cultivate their translation and teaching ability actively for the development of modern, contemporary science, technology and the related contents of science and technology history about China", 93.90\% agree with this view, and 69.3\% strongly agree. On the opinion of " $Q 27$ In the process of real teaching, in addition to the content of science education involved in the English textbooks, I think I can be combined with the latest development of science and technology to supplement the content of science education not covered in English textbooks of senior high school", 91.2\% of the participants agree, only $0.9 \%$ disagree. The mean is 4.51 , the standard deviation is 0.680 , it can be seen that the attitude of teachers on this opinion is basically the same trend.

In the external evaluation, English teachers of senior high school affirmed the necessity of covering science education in English textbooks and teaching science education in English teaching. On the issue of whether the content and presentation of science education in English textbooks of senior high school are perfect, more than $50 \%$ of them agree, which is similar to the statistical analysis of the content and form of science education by internal evaluation. English teachers of senior high school have also affirmed whether students like the multimodal presentation of science education. However, the multimodal presentation of science education also has corresponding requirements on the teaching ability of English teachers in senior high school. First, English teachers should be able to identify and extract the science education in English textbooks of senior high school; secondly, English teachers should be able to master multimodality and flexibly use them in practical teaching. According to the results of the questionnaire, the ability of English teachers to master and flexibly use multimodality needs to be improved.

\section{Conclusion}

The characteristics of science education in China English 
textbooks of senior high school are: 1) it mainly focus on cognition education of science and technology frontier in the distribution of science education, especially the hobbies, technology, music and sports activities of individuals in science. And the content of science education in the three versions of English textbooks of senior high school scatters in some units; 2) it mainly based on the single modal of text in the integration forms of science education; 3) it mainly focuses on NR and offer in the representational and interactive meaning of images; 4) the images of science education of biological quality mainly focuses on bottom-right and center; science education of ecological environment quality mainly focuses on top-right and center; science education of hazard prevention mainly focuses on top-right and bottom-right; cognition education of science and technology frontier mainly focuses on top-right and center in the compositional meaning of images. 5) it mainly focuses on image subordinate to text in the relation of image and text; 7) More importantly, compared with other teaching contents, teachers and students prefer the content of science education; compared with other forms of presentation, they prefer multimodal teaching; and the problem faced by English teachers is to present science education in multimodality and improve the ability of extraction.

To solve problems above, on the one hand, it should increase the proportion of science education appropriately, systematize the content of science education, use multi-modal to present the content of scientific education for editors. On the other hand, English teachers should improve their consciousness of science education in English teaching, be aware of what science education means deeply, master the categories of science education, and be able to supplement the content of science education in English textbooks for senior high school, which is in line with the pace of the times. Secondly, English teachers must strengthen their application ability of multimodality, be able to design teaching combined with relevant contents, and use multimodality in actual teaching to implement teaching in a real sense. At the same time, relevant education departments and schools should also encourage teachers to use multimodality, emphasize the importance of science education in English teaching of senior high school, and provide opportunities for teachers to deeply understand and understand science education and further enrich their knowledge through attending lectures, training and studying abroad. Finally, teachers should participate in relevant training to improve the ability of multimodal application and discrimination of science education actively. Only by improving teachers' ability of multi-modal application and distinguishing science education can we ensure the teaching effect and promote students' comprehensive mastery of English science education.

The limitations of this study lie in the following two aspects: 1) English teachers in senior high schools from seven districts and counties are from Henan Province in China. It is not enough to fully represent the overall situation of all English teachers in senior high schools. However, it is undoubtedly of great significance for the reference to science education in English textbooks of senior high school; 2) some teachers may not choose the answer in their real mind. On the contrary, they choose some pleasant options to submit, which is not conducive to reveal the reality of science education in English textbooks of senior high school; 3) the questions raised in the questionnaire survey are not enough, and the aspects involved are not wide enough. Therefore, the survey results are not as comprehensive as it should be. From view of the above limitations, this study will make further improvements: 1) improve the geographical boundaries of the respondents, increase the survey of English teachers' attitudes towards science education in Englis textbooks in other provinces of China; 2) conduct in-depth interviews with respondents to understand their attitudes towards science education deeply.

\section{Appendix: Survey Questionnaires}

Questionnaires for Teachers

Dear experts and teachers,

Hello! Thanks for participation in this questionnaire survey!

This survey only makes statistics on the content of science education in English textbooks of senior high school for basic education. Please feel free to participate in this questionnaire. There is no right or wrong answer in the questionnaire. Please tick $" \sqrt{ } "$ under your option according to your actual teaching situation. Your opinion is very important to this thesis. Please don't miss any question in the questionnaire. Finally, thank you for your participation in this survey.

Part One: Teachers' personal information survey: please fill in on the line or choose and write the most suitable answers.

Your gender:

Your age:

Whether you are a front-line teacher:

Your grade:

Your teaching experience: $\square$ 1-5 $\square 5-10 \square 10-15 \square>15$ 
English textbook versions in senior high school used by your school or concerned by you:

Part Two: The following topics describe the content of science education in English textbooks of senior high school. Please choose the degree of identification according to the actual situation and your own feelings, give a real answer to each topic and tick the corresponding box $(\sqrt{ })$.

Questionnaires for Teachers.

\begin{tabular}{|c|c|c|c|c|c|}
\hline Topics & $\begin{array}{l}\text { Strongly } \\
\text { Agree }\end{array}$ & $\begin{array}{l}\text { Quite } \\
\text { Agree }\end{array}$ & $\begin{array}{l}\text { Not } \\
\text { Sure }\end{array}$ & Disagree & $\begin{array}{l}\text { Very } \\
\text { Disagree }\end{array}$ \\
\hline
\end{tabular}

I think it is necessary to include the content of science education in English textbooks of senior high school.

I think that the content of science education in English textbooks of senior high school is closely related to students' learning and future life.

I think the content of science education in English textbooks of senior high school can be used as one of the important ways to cultivate students' international vision and inherit science and culture. I think that teaching Chinese science education in the process of English teaching through senior high school would help cultivate students' patriotic enthusiasm and national pride.

I think the content and form of science education in English textbooks of senior high school is rich. Combined with the current situation and the needs of the epidemic situation, I think that biological science education, science information technology education and history of science and technology should be the important contents of science education for students of senior high school.

I think there is a great need to increase the history of science and technology and science education of China in English textbooks of senior high school.

I think the basic English terminology expression and exercises of history about science and technology in China should be increased.

I think the content of science education in English textbooks of senior high school should be presented in a systematic and systematic way.

I think that students are interested in multimodal presentation of science education, such as images, audio and video.

I think that the content of science education in English textbooks senior high school should be presented in multimodal forms such as images, text, audio and video.

I think that I have mastered the characteristics and multimodal forms of science education in English textbooks of senior high school.

I think that the using of multimodal presentation in English textbooks of senior high school is conducive to the introduction and discussion of science education in class.

I think that students are more interested in science education compared with other contents in English textbooks of senior high school.

I think the study of science education in English textbooks of senior high school is conducive to the cultivation of their cross-cultural communication ability and scientific literacy ability.

I think that English science education will focus on the examination in the future.

I think that English teachers should pay attention to guiding students to pay more attention to the contents of biological science education, science information technology education, and history of science and technology in English textbooks of senior high school.

I think that I can accurately extract the information and content of science education in English textbooks of senior high school, and I can study and explore it with students.

I think that English teachers should pay attention to the combination of the current English textbooks of senior high school and cultivate their translation and teaching ability actively for the development of modern and contemporary science and technology and the related contents of science and technology history about China.

In the process of real teaching, in addition to the content of science education involved in the English textbooks, I think I can be combined with the latest development of science and technology to do a supplement to the content of science education not covered in English textbooks of senior high school.

\section{Acknowledgements}

We are grateful for the financial support from Social Science Foundation of Ministry of Education (No. 17YJA740032) and He'nan Social Sciences Planning Project (No. 2018BYY018).

\section{References}

[1] Tiequan Cai, Lihua Chen. (2011). Review of science education research in China. Global Education, 06: 74-83.
[2] Zhanzi Li. (2003). A sociosemiotic analysis of multimodal discourse. Foreign Languages Research, (5): 1-9.

[3] Hailong Tian, Yanyan Pan. (2019). Multimodal Discourse Analysis: Theoretical Exploration and Practical Research. Beihang University Press, 3-260.

[4] Lampiselkä, Jarkko; Kaasinen, Arja; Kinnunen, Päivi; Malmi, Lauri. (2019). Didactic Focus Areas in Science Education, Research Education Sciences, 9, 294.

[5] Halliday, M. A. K. (1985). An Introduction to Functional Grammar. London: Edward Arnold. 
[6] Luis Fernando Santos. (2017). The Role of Critical Thinking in Science Education, Journal of Education and Practice, 8(20): 160-173.

[7] O'Toole, J. M., Freestone, M., and etc. (2018). Types, Topics and Trends: A Ten-Year Review of Research Journals in Science Education. Education Science, 8: 73.

[8] Bateman, J. (2014). Using multimodal corpora for multimodal research. In Jewitt, C. (Ed.), The Routledge Handbook of Multimodal Analysis (pp. 238-252). Abingdon, Oxon; Milton Park, Oxfordshire: Routledge.

[9] Kress, G. R., T. van Leeuwen. (1996). Reading Images: The grammar of Visual Designs. London: Routledge, 10.

[10] Kress, G. R., T. Van Leeuwen. (2006). Reading Images: The Grammar of Visual Design. London: Routledge, 131.

[11] Xiaotang Cheng. (2002). Analysis and design of English textbooks. Beijing: Foreign Language Teaching and Research Press, 15, 54-64.
[12] Ministry of National Education. (2017). Elementary School (Primary and Secondary) Science Curriculum, 3-8th Grades. Ankara. Available from: http://www.mufredat.meb.gov.tr/ProgramDetay.aspx? $P I D=32$ 5 .

[13] Haiyan Yi. (2012). Studies on Science Education Factors and Presentation of PEP's Eight Sets Primary Chinese Textbooks. ZheJiang Normal University, 18-54.

[14] Yan Wang. (2009). A Comparative Study on Scientific Education Factors of Chinese Textbook in Primary School between Mainland and Hong Kong. ZheJiang Normal University, 2.

[15] Xia Tan, Guohua Liu. (2015). Research on the Countermeasures of science education based on the promotion of public scientific literacy. Education Exploration, (10): 28-34.

[16] Fangben Zeng. (2009). Transmutation and Control of Discourse Meaning after the Integration of Multimodalities. Foreign Language Education, 6: 28-32. 